\title{
Student's Perceptions on the Implementation of Youglish in Learning English Pronunciation at English Department
}

\author{
Yanuar Dwi Prastyo $^{1]}$, Yanuarius Yanu Dharmawan ${ }^{2]}$, Sabilla Fitri Amelia ${ }^{3]}$ \\ Universitas Bandar Lampung \\ E-mail: ${ }^{1]}$ yanuar@ubl.ac.id \\ ${ }^{2]}$ yanu@ubl.ac.id \\ ${ }^{3]}$ sabillafitriamelia@ubl.ac.id
}

\begin{abstract}
Pronunciation is one of the most important parts of speaking. The wrong pronunciation can lead to the wrong meaning of the word. Therefore, there should be media to help students understand pronunciation more. There are a lot of media can be used, one of them is YouGlish. The objective of the research is to explore students' perceptions of the implementation of YouGlish in learning English Pronunciation at English Department Universitas Bandar Lampung. YouGlish is a YouTube-based website launched to improve English pronunciation that helps users to find out how to pronounce a word or phrase correctly and appropriately. In this research, the researchers used the descriptive qualitative method. This study was conducted for first semester English students at Universitas Bandar Lampung. This study's instruments were a questionnaire and an interview. The finding shows that students have positive perceptions of the implementation of YouGlish. They perceived that there were several benefits from the use of YouGlish. The results of this research showed students' perception of the implementation of YouGlish in learning English Pronunciation. The questionnaire results also showed mostly positive and negative feedback. The combination of those two instruments is the way to know what the students' perceptions of the implementation of YouGlish in learning pronunciation. In conclusion, YouGlish can make students interested in studying Pronunciation and stimulate students to learn as it has features which will increase the enthusiasm for learning.
\end{abstract}

Keywords: Student's perceptions, pronounciation, implementation of YouGlish

\section{Persepsi Mahasiswa tentang Penerapan Youglish dalam Pembelajaran Pengucapan Bahasa Inggris di Jurusan Bahasa Inggris}

\begin{abstract}
Abstrak
Pengucapan adalah salah satu bagian terpenting dalam berbicara. Pengucapan yang salah dapat menyebabkan arti kata yang salah. Oleh karena itu, perlu adanya media untuk membantu siswa lebih memahami pengucapan. Ada banyak media yang bisa digunakan, salah satunya YouGlish. Penelitian ini bertujuan untuk mengetahui persepsi mahasiswa tentang penerapan YouGlish dalam pembelajaran Pengucapan Bahasa Inggris di Jurusan Bahasa Inggris Universitas Bandar Lampung. YouGlish adalah situs web berbasis YouTube yang diluncurkan untuk meningkatkan pengucapan bahasa Inggris yang membantu pengguna untuk mengetahui cara mengucapkan kata atau frasa dengan benar dan tepat. Dalam penelitian ini, peneliti
\end{abstract}


menggunakan metode deskriptif kualitatif. Penelitian ini dilakukan untuk mahasiswa bahasa Inggris semester satu di Universitas Bandar Lampung. Instrumen penelitian ini adalah angket dan wawancara. Temuan menunjukkan bahwa siswa memiliki persepsi positif terhadap penerapan YouGlish. Mereka menilai ada beberapa manfaat dari penggunaan YouGlish. Hasil penelitian ini menunjukkan persepsi siswa tentang penerapan YouGlish dalam pembelajaran Pengucapan Bahasa Inggris. Hasil kuesioner juga menunjukkan sebagian besar umpan balik positif dan negatif. Penggabungan kedua instrumen tersebut merupakan cara untuk mengetahui bagaimana persepsi siswa terhadap penerapan YouGlish dalam pembelajaran pengucapan. Sebagai kesimpulan, YouGlish dapat membuat siswa tertarik untuk mempelajari Pengucapan dan merangsang siswa untuk belajar karena memiliki fitur yang akan meningkatkan semangat belajar.

Kata kunci: Persepsi siswa, pengucapan, implementasi YouGlish

\section{INTRODUCTION}

English is not commonly used by speakers in Indonesia. It is only used in foreign companies, educational institutions, and foreign offices. Compared to other foreign languages such as Arabic, French, German, Mandarin, and Japanese, English can be said to be the main foreign language. For English learners, there are four important skills, involving reading, listening, writing, and speaking.

There are several components of speaking involved in the speaking process. Speaking skills have at least five components concerned with pronunciation, grammar, accuracy, vocabulary, and fluency. Those are some components of speaking skills that should be understood and mastered. Pronunciation is one of the most important parts of speaking. The wrong pronunciation can lead to the wrong meaning of the word. In many cases, misunderstanding in communication is caused by misspelled words or incorrect pronunciation. For example, if someone says the words "two" and "to" with relatively no difference in pronunciation, this can cause misunderstanding. For most students, English pronunciation was one of the most difficult skills to master. Students' limitations in mastering pronunciation can negatively affect the students' learning process. Some students can write fluently but have difficulty speaking. Students are afraid of making mistakes and of not being understood by their friends. They cannot express their ideas in English completely, especially in speaking.

Pronunciation learning media usually use technological assistance. Some technologies commonly used in pronunciation learning are software and websites. One of the technological media that will be used in teaching English pronunciation in this research is YouGlish. The following are some websites that are commonly used to improve pronunciation. YouGlish is a tool that makes it easy for students to know how to pronounce English words using YouTube videos from native speakers. Students can choose the pronunciation of English, US, AUS or all other pronunciations. While students hear the words they want to learn, students can also read the available transcripts.

In connection with the explanation above, this study is important to determine how YouGlish is implemented in teaching English pronunciation. There has been some research in relation to YouGlish (Mccarathy, 2018). However, their research focused on evaluating the progress of EFL learners in speaking during an intervention in which they used YouGlish as a learning tool, 
stimulating interest in using YouGlish when making lexicography decisions, and investigating the impact of extensive listening exercises (conducted by YouGlish) on the production of mispronounced words. The difference with my research is that my research focused on exploring the procedure of implementation of YouGlish in learning English pronunciation. In addition, this study also explores students' perceptions of using YouGlish for learning pronunciation. Therefore, this research is important to be conducted as this research will fill the gap between the available research and what the public know about YouGlish. The objective of this paper is to explore students' perceptions of the implementation of YouGlish in learning English Pronunciation at English Department Universitas Bandar Lampung.

\section{Literature Review}

\subsection{The Concept of Speaking}

Speaking is an important part of improving one's English skills. Samad, et.al (2017) states that speaking is the act of producing a vocal sound, helping the listener understand the message in a way that is convincing and wise. Speaking means the process of communicating with one another in conveying the same or different thoughts. Through speaking, everyone can express their minds, ideas and thoughts freely and spontaneously. Speaking helps students develop their vocabulary and grammar skills. It also improves their writing skills.

\subsection{Aspects of Speaking}

Speaking not only requires a vowel sound but also needs to pay attention to speaking aspects, which include pronunciation, fluency, grammar, accuracy, and vocabulary. Aspects of speaking are very necessary to measure students' speaking ability.
1. Pronunciation

Pronunciation is the knowledge of learning how words are produced clearly when we speak. What we talk about must be acceptable if there is an error in pronunciation.

2. Fluency

Evidence of fluency in speaking can be seen from the speed of speech and only a few pauses. Fluency means how someone can communicate without pause or hesitation. For example, in a conversation, a learner can make a grammatical error, such as Maria live in Cazenga [live vs. lives]), but the learner can still speak the sentence with some fluency (Crowther et al., 2015).

3. Grammar

Grammar is essentially one of the language components that study the arrangement of the sentences about the verb and the time (Yanuar, et al. 2013). It determines the structure of language and can be a way to combine units of language. This is necessary for students to be able to arrange correct sentences in conversation. However, grammar is very often ignored in speaking, especially when non-native speakers speak.

4. Accuracy

Accuracy focuses on words that are understood, true in structure, syntactic, and better at capturing the meaning of language messages (Kusnierek, 2015). It means understanding the deeper meaning and usage of vocabulary and also involves the correct pronunciation of words.

5. Vocabulary

Vocabulary is a word that has meaning in every function (Samad, et.al, 2017). A word expresses the meaning of the word to avoid confusion in communication. The more vocabulary 
we have, the better we speak. Students also need to know what these words mean and how to use them correctly.

\subsection{The Concept of Pronunciation}

Pronunciation plays an important role in English speaking to express our ideas. Without proper pronunciation, people will misunderstand what someone is talking about. By mastering pronunciation skills, everyone will be able to pronounce words correctly. This will increase their confidence in speaking English and increase their speaking confidence. Having a good pronunciation of the language also makes it easier for us to speak clearly to others. Wrembel (2002) expresses that pronunciation instruction has several realistic goals for developing communicative competence. It means improving pronunciation is not only to show that you are good at speaking English, but it is also an important goal to develop your communication skills. Because in communicating, there are several goals that we should achieve.

\subsection{Teaching of Pronunciation}

Teaching of pronunciation is the most complicated but important aspect for students (Handayani, 2017). In the process of teaching pronunciation, teachers must pay attention to the role of the teacher towards students. Teachers must discuss what is appropriate and in accordance with student learning styles. Gilakjani (2016) expresses the important role of practicing pronunciation is to see student development. The teacher must set attainable goals that are appropriate for the student's communication needs. Teachers must find an appropriate way to teach pronunciation so that the learning process becomes more fun. To improve students' pronunciation skills, the teacher must play an active role in finding techniques and media that can be applied in the classroom. Rao (2014) states the use of media will complement the teaching and learning process. There are several websites currently that aim to help students improve their English pronunciation. YouGlish allows students to see and hear how native speakers pronounce words in English correctly and clearly. There are many ways and media that students can use to improve their pronunciation skills. One of them is by using YouGlish.

\subsection{The Concept of YouGlish}

YouGlish is a YouTube-based website launched to improve English pronunciation. As of December 2020, YouGlish has more than 50 million tracks. YouGlish helps users to find out how to pronounce a word or phrase correctly and appropriately and YouGlish shows how native speakers pronounce the word or phrase in actual context. The videos on YouGlish come from YouTube. That is why the name of the website comes from 'YouTube' and 'English' (Mccarthy, 2018). There are three accents used in YouGlish. Those are US accents, UK accents, and AUS accents. You can choose any accent you want to watch or use. When we watch videos according to what we are looking for, below the video there are subtitles that make it easier for us to learn the word. YouGlish can be accessed from any device that has a web browser and is very easy to use.

\subsection{Using YouGlish}

This study reveals how YouGlish helps students to improve their pronunciation. This tool also contains enough material in it so that we can investigate the pronunciation of rare words. $\mathrm{Fu}$ and Yang (2019) stated that by using YouGlish as an instructional resource, learners can be converted into information generators rather than knowledge receivers, which demonstrates that passive learning is not necessary for acquiring oral skills in 
English through video usage. Difficulties in pronunciation can be overcome with YouGlish. This website is designed for students learning English. Because of the speed and effectiveness that makes YouGlish a powerful tool for knowing how to pronounce in English. The use of YouGlish in pronunciation is a very effective way. YouGlish provides a good model for teaching pronunciation. The students can imitate the model of the speaker.

There are some processes in using YouGlish. First, you should open YouGlish in web https://youglish.com/. Second, write the word or phrase that you want to learn. And the last, after you find out the word or phrase, a list of videos related to the word you are looking for will appear under the search field, in that video there is a title, time and options to share the title link to the original video on YouTube.

Below the video column, the subtitles will appear that match the word or phrase we are looking for and also some words that are close to what we search. YouGlish also has phonetic in it, there is an international phonetic alphabet (IPA) modern and traditional spelling of the word and there is also a collection of words that have similarities to the word we search. YouGlish also provides tips for making your pronunciation perfect.

\subsection{Students' Perception}

Perception is one of the important psychological factors, since we know the kinds of processes that occur in our environment by perception (Kurniawan, 2015). Individuals have different opinions on an object; it can be either positive or negative. Perception is automatically added to a human being's certain existence, which is its psychological character. Teachers cannot teach without students, but students can learn from teachers. Kurniawan (2015) claimed that the perception of students is the process of special consideration of students towards knowledge obtained from an object. Students might interpret the observed object through observations with their senses. These expectations influence the ability of students to actually participate in question and answer sessions.

\subsection{Factors of perception}

There are three factors influencing perception. The first one is the perceiver. An individual is affected by his characteristics such as values, behaviors, motivations, desires, experiences, cognitive systems, perceptions and cultural knowledge while looking at things and attempting to provide an explanation. The second aspect is the perceived object or target. They may be people, objects or activities. This influences the perception of the individual. The goal of perception is not something seen theoretically, but in reference to other individuals involved. This allows individuals, objects, or activities to be classified similarly, and separated from other groups. The stronger the similarity, the more likely the group is to be viewed, and opposite. The third is the sense in which the experience is conveyed. Aspects in the environment affect our experience. Perception should be perceived contextually, which means that focus should be given to the situation where perception appears. The condition leads to the process of determining the understanding of an individual. The situation includes time, job and social circumstances.

\section{METHOD}

In this research, the researchers used a qualitative method. Qualitative research focuses on multiple methods and provides an interpretative, naturalistic approach to its subject matter (Aspers and Corte, 2019). This qualitative research process involves 
important efforts, such as asking questions and procedures, collecting specific data from participants, analyzing data inductively starting from specific themes to general themes, and interpreting the meaning of data. According to Yanuar (2017), qualitative research is defined as an investigation procedure focused on distinct empirical investigation traditions, examining a social or human issue. I describe how students perceived the use of YouGlish in learning English pronunciation. There are two ways to do this research. First, I distributed the questionnaire to the students, followed by an interview as the primary data source. Finally, I analyzed and described all the data.

This research was conducted in the $1^{\text {st }}$ semester by students of the English Department at Universitas Bandar Lampung. Purposive sampling was used for the questionnaire and interviews in this study. The total population was 54 students. From the population, there were 20 students who have been the participants of this research and 6 students who have done the interview. The reason why the researcher only chose 20 students is because some of the students when the researcher asked them to be her participants gave reasons such as difficulty getting a signal, no quota, busy with lectures, etc. And the reason the researcher only chose six students for the interview was because the students provided positive feedback in the questionnaire and met the criteria that the researcher desired.

\section{FINDINGS AND DISCUSSION Findings}

In this part, the researchers would present the result of the research. The data was taken from questionnaire given to English Department Study Program students in University of Bandar Lampung. The students were asked to answer the questionnaire related to the implementation of YouGlish. After collecting the data, the researcher analyzed the data.

\section{The Result of Usability}

Usability is a measure of how well students can use YouGlish to achieve a defined goal effectively, efficiently and satisfactorily in improving students' pronunciation.

Table 1 . The result of usability

\begin{tabular}{|c|c|c|c|}
\hline $\begin{array}{l}\text { Question } \\
\text { Number }\end{array}$ & Statements & \multicolumn{2}{|c|}{ Responses } \\
\hline \multirow{5}{*}{1.} & \multirow{5}{*}{$\begin{array}{c}\text { Your } \\
\text { experience } \\
\text { using } \\
\text { YouGlish. }\end{array}$} & $\begin{array}{l}\text { Very } \\
\text { Fun }\end{array}$ & 7 \\
\hline & & Fun & 11 \\
\hline & & Neutral & 2 \\
\hline & & Not Fun & 0 \\
\hline & & $\begin{array}{c}\text { Very } \\
\text { Not Fun }\end{array}$ & 0 \\
\hline \multirow{5}{*}{3.} & \multirow{5}{*}{$\begin{array}{c}\text { Experience in } \\
\text { using } \\
\text { YouGlish. }\end{array}$} & $\begin{array}{l}\text { Very } \\
\text { Easy }\end{array}$ & 9 \\
\hline & & Easy & 6 \\
\hline & & Neutral & 5 \\
\hline & & Difficult & 0 \\
\hline & & $\begin{array}{c}\text { Very } \\
\text { Difficult }\end{array}$ & 0 \\
\hline
\end{tabular}

The table above shows the result regarding the experiences of using YouGlish in the classroom based on students' perceptions. It shows that most students feel that the use of YouGlish is fun and easy to use in learning pronunciation in the classroom. Thus, it is indicated that $90 \%$ of students have a good response to the experience using YouGlish in learning pronunciation. This result was supported by the result of the respondent in the open- 
ended comments. The comments of the students were written by the code. S4 means comment from student's number 4. QOA means question.

"Make it easy to learn pronunciation well and correctly"

(QOA10)

"It really helps. Learning pronunciation is not an easy thing, but with YouGlish my learning has become more fun and easy"

(QOA4)

To strengthen the results of the experiences of using YouGlish, the results of the data from interviews also give good responses to the use of YouGlish. All the respondents that $\mathrm{I}$ had been interviewed stated YouGlish is really fun and easy because, for them, as students, YouGlish really makes it easier to learn, like if there were words that were difficult to pronounce and after using YouGlish it became easy to know how to pronounce the word.

"Makes it easy for us to use proper and correct Prono, it can also help determine syllables and much more unciation but not only in pronunciation in English

(S2)

"I really like YouGlish because as a beginner I really need an application that supports and makes it easy for my learning process"

(S4)

Overall, it may be said that students' experiences of using YouGlish are fun and easy for learning pronunciation.

\section{The Result of Helpfulness}

Helpfulness categorize the use of YouGlish in giving the benefit and help students to identify certain topic related pronunciation.
Table 2. The result of helpfulness

\section{Question Number \\ Statements Responses}

Very Fun 7

Fun

1.

$$
\text { Your }
$$

Neutral 2

experience

using

YouGlish.

Not Fun 0

Very Not 0

Fun

Very Easy $\quad 9$

Easy 6

3.

Experience in

Neutral 5

YouGlish.

Difficult 0

$$
\text { Very }
$$

Difficult

The table above shows the result regarding the experiences of using YouGlish in the classroom based on students' perceptions. It shows that most students feel that the use of YouGlish is fun and easy to use in learning pronunciation in the classroom. Thus, it is indicated that $90 \%$ of students have a good response to the experience using YouGlish in learning pronunciation. This result was supported by the result of the respondent in the openended comments. The comments of the students were written by the code. S4 means comment from student's number 4. QOA means question.

"Make it easy to learn pronunciation well and correctly"

"It really helps. Learning pronunciation is not an easy thing, but with YouGlish my learning has become more fun and easy" 
(QOA4)

To strengthen the results of the experiences of using YouGlish, the results of the data from interviews also give good responses to the use of YouGlish. All the respondents that I had been interviewed stated YouGlish is really fun and easy because, for them, as students, YouGlish really makes it easier to learn, like if there were words that were difficult to pronounce and after using YouGlish it became easy to know how to pronounce the word.

"Makes it easy for us to use proper and correct Prono, it can also help determine syllables and much more"unciation but not only in pronunciation in English

"I really like YouGlish because as a beginner I really need an application that supports and makes it easy for my learning process"

It can be concluded that students' experiences of using YouGlish are fun and easy for learning pronunciation.

The questions in the table above concern improving students' abilities to use YouGlish. The result of the use of YouGlish in learning Pronunciation is about $85 \%$ or 17 students who feel helpful. Through YouGlish videos, improve your pronunciation skills. The results show that 15 or $85 \%$ of students agree that YouGlish improves students' skills. It was supported by statements in the open-ended question that stated,

"YouGlish helped me know how to pronounce English words that I didn't know before"

(QOA8)

To strengthen the results of using YouGlish, the results of the data from interviews also give good responses to the use of YouGlish. All the respondents that I had been interviewed stated YouGlish is really helpful because for them, as students,
YouGlish helps them to learn pronunciation and YouGlish really makes it easier to learn, like if there were words that were difficult to pronounce and after using YouGlish it became easy to know how to pronounce the word.

"In my opinion, the use of YouGlish is very helpful in learning good and correct pronunciation, especially with the video that directly exemplifies how to pronounce the correct word/sentence"

As a result, the use of YouGlish in the classroom improves students' pronunciation skills because the majority of students agree to the questions. There are several arguments from open-ended questions that support YouGlish in improving pronunciation, as stated by one of the respondents,

"Increasingly know how to pronounce English words, pronunciation accuracy, and stress in Pronouncing"

(QA07)

The result of interview was also shown that YouGlish help students in improving their pronunciation.

"In my opinion, after I try it, it really helps, because the pronunciation in YouGlish is clear, and we can understand more quickly and the Pronounciation can be repeated, and then what we search for the word that we want to know how to pronounce will be filled by the YouGlish, and also YouGlish will be an effective tool for me to learn pronunciation,"

Overall, it may be said that students' feel using YouGlish improves their skills for learning pronunciation. 
The Result of Accessibility

Table 3. The result of accessibility

\begin{tabular}{|c|c|c|c|}
\hline $\begin{array}{l}\text { Question } \\
\text { Number }\end{array}$ & Statements & Respo & \\
\hline & & Strongly & 12 \\
\hline & You can & & \\
\hline & & Agree & 6 \\
\hline 5. & $\begin{array}{l}\text { YouGlish } \\
\text { anvwhere }\end{array}$ & Neutral & 2 \\
\hline & and & Disagree & 0 \\
\hline & anytime. & Strongly & 0 \\
\hline & & Disagree & \\
\hline & & Very & 9 \\
\hline & & Easy & 5 \\
\hline 6 & the features & Neutrol & 4 \\
\hline 0. & & Neutral & \\
\hline & YouGlish. & Difficult & 2 \\
\hline & & $\begin{array}{c}\text { Very } \\
\text { Difficult }\end{array}$ & 0 \\
\hline
\end{tabular}

The next result is about the result of students' perceptions of accessibility in using YouGlish. According to the data above, $90 \%$ of respondents agree that the accessibility of YouGlish can be used anywhere and at any time, with only two respondents choosing neutral because they don't know whether to agree or disagree, and no respondents disagree about the accessibility of using YouGlish. From the results of this statement, many respondents agree that the accessibility of YouGlish can be used anywhere and anytime. The reasons are because during this pandemic they could not go to campus. The existence of YouGlish helped them to learn pronunciation and they can use YouGlish however they like. The comments of the students were written by the code. S4 means comment from student's number 4. QOA means question. In response to an openended question, one respondent stated,

"I can find it easier to know the pronunciation of words that I didn't know before, and YouGlish can make it easier for students in this covid-19 era"

(QOA9)

"We don't need to study outside again during the current pandemic. By studying English, we can learn pronunciation and so on"

(QOA11)

The result from understanding the features in YouGlish It has 14 students who feel easy, so it is about 70\%, 4 students or $20 \%$ feel neutral because they can't choose whether easy or difficult and about 2 or $10 \%$ of students answer difficult. Most of the students felt it was easy to understand the features in YouGlish. It is stated by the respondent in the open ended question that,

"Students can use YouGlish everywhere and anytime"

(QOA15)

"I really like YouGlish because as a beginner I really need an application that supports and makes it easy for my learning process"

The other respondent stated that YouGlish is simple to find word that they want to know how to pronounce, as stated

"Using YouGlish is simple, if you want to find a word that you want to know, just type it straight out"

On the other hand, one respondent stated in an open ended question that YouGlish is difficult to use because it difficult to imitate.

"The way it is pronounced in the video is too rushed, so it's difficult to imitate the Pronunciation.”

As a result, students agree that the accessibility of YouGlish can be used 
anywhere and at any time. There are two who say that YouGlish features are difficult to understand, on average, other respondents feel the experiences of using YouGlish and YouGlish features is easy to understand for learning pronunciation.

\section{The Result of Future Use}

Table 4. The result of future use

\begin{tabular}{cccc}
\hline $\begin{array}{l}\text { Question } \\
\text { Number }\end{array}$ & Statement & Responses \\
\hline & & Strongly & 11 \\
& Agree & \\
Ysing & Agulish as & Agree & 7 \\
a media for & Neutral & 2 \\
& $\begin{array}{c}\text { learning } \\
\text { pronunciation } \\
\text { in the future. }\end{array}$ & Disagree & 0 \\
& & Strongly & 0 \\
& & Disagree & \\
\hline
\end{tabular}

From the result above, related to YouGlish as a learning media for the future. The result shows that $90 \%$ of respondents agree that YouGlish will be a medium for learning pronunciation in the future and only one respondent that chose a neutral course doesn't know to choose whether to agree or disagree. This statement was approved by a statement from an interview that stated,

"I tried an application for pronoun learning but it turned out to be complicated and it couldn't be repeated, so when I used Youglish it turned out to be more efficient" (S1)

"Because by watching the video from YouGlish we can hear the native speaker pronounce each word"

(S6)

As a result, it can be concluded that YouGlish may become a learning media for pronunciation in the future because it is efficient and they enjoy watching videos from YouGlish and imitating native speakers from YouGlish.

\section{The problems of YouGlish}

From the results that the researcher got from open ended questions and interview, there are some problems that are stated by the respondents, these are related to internet connection and accessibility.

Internet connection becomes the main problem found in respondent statements regarding the use of YouGlish. In an open-ended question, the researcher asked about problems with using You English for pronunciation learning.

"Unstable internet connection"

(QOA3)

This was also supported by several respondents when interviewed.

"It is about the signal, using your English have to use the internet. For example, if the signal is down, it's a bit buffering"

"For now, maybe only in the signal because YouGlish cannot be used offline"

As a result, it is possible to conclude that the internet connection is the issue because when students use YouGlish when the internet connection is unstable, it makes it difficult for them to watch videos on YouGlish.

Even though the questionnaire results explained that YouGlish can be used anywhere and at any time, there are still issues that were discovered in the interview results, which stated that there are several things that make YouGlish inefficient.

"YouGlish can only be accessed if you have a good internet connection"

So, it can be concluded that because YouGlish is still web-based and not in the form of an application, some of them find it difficult if they want to use YouGlish when they don't have an internet connection because YouGlish cannot be used offline either. 
The Suggestions on the Implementation of YouGlish in Learning English Pronunciation in the Future

The results of the questions asking for suggestions for the use of YouGlish, which were found from the interview, are as follows:

"I believe it is a very good idea if YouGlish is used as a website for pronunciation learning in the future, because it makes it easier for students or others to learn pronunciation, and the website is easy to remember."In addition, students also really need YouGlish to learn pronunciation because many students have the wrong pronunciation of English"

"I think it is good to use YouGlish for pronunciation learning, because by watching the YouGlish video of pronunciation, we can understand better and make it easier to pronounce every word"

"In my opinion, the use of YouGlish can be applied as a means of learning pronunciation for students/people who want to understand how to pronounce English words correctly, especially when we can access YouGlish easily"

"My advice is that when you use YouGlish you have to understand the features in YouGlish so that it makes it easier for you to use and understand so as not to make it difficult"

\section{Discussion}

As this research is aimed at exploring students' perceptions on the implementation of YouGlish in teaching pronunciation, four indicators have been set for students' pronunciation which include effectiveness, understanding, flexibility, and efficiency. From the result of the questionnaire and interview, YouGlish has several positive effects in helping students to learn pronunciation. YouGlish is really helpful because for them, as students, YouGlish helps them to learn pronunciation. YouGlish is perceived to make it easier to learn and after using YouGlish it became easy to know how to pronounce the word. YouGlish can be used anywhere and anytime. The reasons are because during this pandemic they could not go to campus. The existence of YouGlish helped them to learn pronunciation and they can use YouGlish however they like. These results correspond to Syunina et al.'s (2017), finding that students improved their speaking skills with authentic video materials, such as those featured in YouGlish (Kozhevnikova, 2014). Hakim (2016) stated that pronunciation and intonation improved the most by demonstrating a wider scope of the benefits of video in combination with the lexical approach.

There are problems that the students' faced by using YouGlish. Internet access is the problem, as it makes it impossible for students to view videos on YouGlish while the internet is unstable. Second, this is the result of the accessibility that researchers discovered in the interview. Even though the questionnaire results explained that the accessibility of using YouGlish can be used anywhere and at any time, there are still issues that were discovered in the interview results, which stated that there are several things that make YouGlish inefficient.

\section{CONCLUSION}

There are currently several websites designed to help students improve their pronunciation of English. According to digital integration of education, several technologies are built to support teaching, such as YouGlish. There are many forms and ways to develop the ability of students to speak. YouGlish is an English pronunciation Website launched on 
YouTube. YouGlish enables students to see and hear the languages in English correctly spoken by native speakers. YouGlish's over 50 million tracks are available from December 2020. It explains how native speakers talk the word or the expression in real context. The goal of this research was to study the views of students regarding implementing YouGlish in English pronunciation teaching. In addition, this thesis study builds conducted to explore how strong, weak and suggested YouGlish is implemented in English pronunciation teaching. The research also looked at how people use YouGlish for improvement of pronunciation. The main findings from the study show that the usage of YouGlish has an important impact on the pronunciation of frequently mispronounced terms by students.

By doing this study, the researchers get some insights into how students see YouGlish as a website helping to learn pronunciation. YouGlish is a good way for students to use in class because it is more realistic for learning process. In addition, YouGlish can make students interested in studying because it is a website and can involve them with an enthusiastic interest in learning the subject. In addition, the use of YouGlish will stimulate students to learn as it has features which will increase the enthusiasm for learning. And then it will solve the difficulty some words that be difficult for the students to pronounce.

\section{REFERENCES}

Aspers, P., \& Corte, U. (2019). What is Qualitative in Qualitative Research. Qualitative Sociology, 42(2), 139160. https://doi.org/10.1007/s11133019-9413-7.

Crowther, D., Trofimovich, P., Isaacs, T., Saito, K. (2015). Does a speaking task affect second language comprehensibility? Modern
Language Journal, 99, 80-95. doi:10.1111/modl.12185.

Fu, J. S., \& Yang, S. H. (2019). Exploring how YouGlish facilitates EFL learners' speaking competence. Educational Technology and Society, 22(4), 47-58.

Gilakjani, A. P. (2016). English Pronunciation Instruction: A Literature Review. International Journal of Research in English Education, 1(1), 1-6. http://ijreeonline.com/article-1-21en.html.

Hakim, M. I. (2016). The use of video in teaching English speaking (A quasiexperimental research in senior high school in Sukabumi). Journal of English and Education, 4(2), 44-48.

Handayani, D. I. F. (2017). Teaching English Pronunciation using Film. Department of English Education, Indonesia University of Education.

Kozhevnikova, E. (2014). Exposing students to authentic materials as a way to increase students language proficiency and cultural awareness. Social and Behavioral Sciences, 116(2014), 4462-4466. doi:10.1016/j.sbspro.2014.01.967.

Kurniawan, R. (2015). Students' Perceptions of Teachers' Classroom Questioning. Unpublished Bachelor Thesis, Universitas Muhammadiyah Purwokerto: Purwokerto.

Kusnirek. (2015). Developing Students' Speaking Skill through Role-Play. 73-111. World Scientific News 1.

Mccarthy. D. (2018). A Promising Tool for Pronunciation Dictionary. Lexicography Arecls, Vol. 15, 2018, P. 81-96. 15, 81-96. Youglish.com.

Prastyo, Y.D., (2018). Effect of Cooperative Learning on Student Teachers' Communicative Competence in 
Indonesia. Ph.D Dissertation, University of Limerick, Ireland.

Prastyo, Y.D., Septi, N., \& Imam, S. (2013). Analysis of Students' Gramatical Error in Using Present Continuouse Tense. Faculty of Teacher Training and Education, Bandar Lampung University.

Rao, B. M. (2014). Use of media as an instructional tool in English Language Teaching (ELT) at undergraduate level. International Journal of English and Literature, $5(6)$, 141-143. https://doi.org/10.5897/ijel2014.0580

Samad, I. A., \& Adnan, Z. (2017). Using a Genre-Based Approach to Prepare Undergraduate Students for an English Thesis Defence Examination: an Experimental Study to Address the 'Pedagogical Controversy.' Linguistik Indonesia, 35(1), 75-93. https://doi.org/10.26499/li.v35i1.56.

Syunina, A. S., Yarmakeev, I. E., Shechter, D., Pimenova, T. S., \& Abdrafikova, A. R. (2017). Authentic video materials as a means of speech fluency development in EFL class. Modern Journal of Language Teaching Methods, 72(9), 034-040.

Wrembel, M. (2002). New Perspectives on Pronunciation Teaching. In W. Sobkowiak and E. WaniekKlimczak. Dydaktyka Fonetyki Języka Obcego na Poziomie Licencjackim, Neofilologia II: Zeszyty Naukowe PWSZ w Płocku, 173-183. 